\title{
MODEL PENENTUAN BATAS WILAYAH KELOLA MASYARAKAT HUKUM ADAT LAOT; STUDI KASUS WILAYAH LHOK KUALA CANGKOI, ULEE LHEU
}

\author{
Teuku Muttaqin Mansur ${ }^{1}$, M Adli², $^{2}$ Sulaiman $^{3}$ \\ ${ }^{123}$ Dosen Fakultas Hukum Universitas Syiah Kuala, \\ Darusalam, Banda Aceh. \\ Email : teuku.muttaqin@unsyiah.ac.id
}

Diterima: 15/08/2020; Disetujui: 31/08/2020

\begin{abstract}
ABSTRAK
Artikel ini bertujuan menjelaskan mekanisme penentuan wilayah kelola masyarakat hukom adat laot (WK-MHAL) Lhok Kuala Cangkoi, Banda Aceh. Metode pelaksanaan diawali dengan sosialisasi penentuan wilayah kelola, penentuan wilayah kelola, merumuskan kesepakatan, dan membuat peta WK-MHAL Lhok Kuala Cangkoi. Penentuan WK-MHAL baru dapat dihasilkan setelah dilakukan serangkaian sosialisasi dan pendampingan melalui pertemuan-pertemuan langsung dan tidak langsung dengan pemangku kepentingan dan masyarakat dalam wilayah Lhok Kuala Cangkoi. Terdapat delapan kesepakatan yang disepakati yaitu, tentang batas wilayah kelola dan tujuan, kewenangan panglima laot lhok dan panglima teupin, dan tata cara meupayang / penangkapan ikan. Untuk tata cara meupanyang maka dikelompokkan dalam dua bagian yaitu tentang tata cara meupayang (penangkapan ikan) dengan boat labi-labi/pukat laut, tata cara meupayang (penangkapan ikan) dengan menggunakan pukat darat, dan tata cara meupayang (penangkapan ikan) dengan menggunakan alat tangkap jarring. Selanjutnya peraturan yang dihasilkan adalah berkaitan hari pantangan melaut, larangan khusus menggunakan bom, pembiusan dan kompresor, dan sanksi para pelanggar.
\end{abstract}

Kata Kunci: Wilayah Kelola, Masyarakat Hukum Adat Laot, Lhok Kuala Cangkoi 
Model Penentuan Batas Wilayah Kelola Masyarakat Adat Laot; Studi Kasus Wilayah Lhok Kuala Cangkoi, Ulee Lhe Teuku Muttaqin Mansur, M. Adli, Sulaiman.

\section{PENDAHULUAN}

Lembaga Panglima Laot Lhok ${ }^{1}$ Kuala Cangkoi, Banda Aceh membawahi 12 teupin, yakni: Teupin Asoe Nanggroe, Teupi Uleelheu, Teupin Gampong Pie, Teupin Pintoe Ie Lambung, Teupin Pante Cermin, Teupin Ujung Kuala, Teupin Ulee Cot Lambung, Teupin Ulee Cot ,Teupin Ulee Cot Alu Deah Geulumpang, Teupin Alue Deah Baro, Teupin Alue Deah Teungoeh, Teupin Lampaseh. Saat ini, wilayah kekuasaan Lhok Kuala Cangkoi dijadikan sebagai salah satu zonasi pencadangan konservasi wilayah laut Aceh yang akan dimasukkan dalam Qanun Aceh tentang Rencana Zonasi Pengelolaan Wilayah Pesisir dan Pulau-pulau Kecil (RZWP3K) yang tengah disusun oleh Dinas Kelautan dan Perikanan (DKP) Aceh.

Kelembagaan Panglima Laot berharap supaya wilayah konservasi tersebut berbentuk wilayah kelola laut berbasis hukum adat, di mana secara kearifan lokal telah dijalankan secara turun temurun. Berdasarkan Undang Undang Nomor

\footnotetext{
${ }^{1}$ Lhok adalah teluk. Secara terminology, lhok merupakan sebuah wilayah yang didiami oleh sekelompok nelayan, dipimpin oleh seorang yang dipilih dan dituakan untuk memimpin wadah masyarakat nelayan (disebut Panglima Laot Lhok), dan memiliki wilayah kelola laut penangkapan dan tempat pendaratan ikan (di wilayah pantai atau pesisir). Lhok secara historis dapat berupa teluk(an), muara, tepian pantai ataupun terusan-yang lebih menjorok ke arah darat. Dibeberapa kawasan lhok di Aceh yang nelayannya relatif tersebar, dijumpai juga terminologi Panglima Teupin yang tunduk kepada Panglima Laot Lhok. Saat ini di Aceh terdapat \pm 176 Lhok. Lihat Teuku Muttaqin Mansur dan Marzuki,"Pengelolaan Kawasan Konservasi Perairan Daerah Di Provinsi Aceh Berbasis Kearifan Lokal (Hukum Adat Laot)", Jurnal Geuthèë: Penelitian Multidisplin, vol 1 no 1, (Maret 2018), (65-74), hlm. 66.
}

Jurnal Geuthèë: Penelitian Multidisiplin Vol. 03, No. 02, (Agustus, 2020), pp465 - 472.
27 Tahun 2007 tentang Pengelolaan Wilayah Pesisir dan Pulau-pulau, bahwa dalam penyusunan RZWP3K, pemerintah dan pemerintah daerah memperhatikan kearifan lokal dan kelestarian laut.

Di Aceh, penguatan pengolalan sumber daya alam baik di darat dan laut selain mengikut kepada perundang-undangan yang berlaku nasional, juga terikat kepada undang-undang khusus, Undang-Undang Nomor 11 tahun 2006 tentang Pemerintahan Aceh. Pasal 162 ayat (1) menyatakan bahwa, "Pemerintah Aceh dan pemerintah Kota/kota berwenang untuk mengelola sumber daya alam yang hidup di laut wilayah Aceh."

Potensi pengelolaan sumber daya alam wilayah pesisir melibatkan lembaga adat sangat besar. Hal ini karena, Aceh memiliki Lembaga Panglima Laot yang selama 400 tahun lalu menjaga wilayah pesisir (wilayah kelola) dengan konsep kearifan lokal. Namun demikian, perkembangan masyarakat dan pembangunan dewasa ini, menyebabkan keberadaan kearifan lokal mulai terkikis oleh kepentingan pribadi, kelompok, dan industrilisasi. Sehingga wilayah kelola adat yang selama ratusan tahun yang lalu mulai digugat keabsahannya dan terkadang dipertentangkan dengan hukum positif (hukum tertulis). Lembaga Panglima Laot Lhok Kuala Cangkoi masih tetap berusaha mempertahankan kearifan lokal wilayah kelola adat secara tradisional (tidak tertulis). Namun, pada saat yang 
Model Penentuan Batas Wilayah Kelola Masyarakat Adat Laot; Studi Kasus Wilayah Lhok Kuala Cangkoi, Ulee Lhe Teuku Muttaqin Mansur, M. Adli, Sulaiman.

sama khawatir apabila wilayah mereka dialihkan untuk kepentingan yang merusak sumber daya ikan dan lingkungan.

Berdasarkan uraian di atas, artikel ini ingin menjawab bagaimanakah mekanisme penentuan wilayah kelola masyarakat hukom adat laot (WK-MHAL) Lhok Kuala Cangkoi Banda Aceh, bagaimanakah kesepakatan bersama tentang penentuan wilayah kelola hukom adat laot dihasilkan, dan bagaimanakah peta wilayah kelola hasil kesepakatan.

\section{METODE PENELITIAN}

Pasal 1 huruf a dan huruf $\mathrm{b}$ konvensi International Labour Organization (ILO) 169 1989 menyepakati bahwa masyarakat adat di dalam Negara-negara bangsa sudah merdeka dapat diidentifikasikan melalui kondisi sosial, budaya, dan ekonomi yang statusnya di atur sepenuhnya atau sebagianya dengan adat atau tradisi mereka atau dengan hukum atau regulasi yang khusus.

Di Indonesia, keberadaan masyarakat hukum adat beserta hak-hak tradisionalnya diakui melalui Pasal 18B ayat (2) UndangUndang Dasar (UUD) Republik Indonesia Tahun 1945, yang berbunyi: 'Negara mengakui dan menghormati kesatuan masyarakat hukum adat beserta hak-hak tradisionalnya sepanjang masih hidup dan sesuai dengan perkembangan masyarakat dan prinsip negara Kesatuan Republik Indonesia, yang di atur dalam undangundang."
Di sisi lain, negara Indonesia merupakan Negara kepulauan (archipelago state) terbesar yang terdiri atas 17.504 pulau, termasuk 9.634 pulau yang belum diberi nama dan 6.000 pulau yang tidak berpenghuni, 740 suku bangsa/etnis dengan 583 bahasa dan dialek dari 67 bahasa induk yang digunakan berbagai suku bangsa. Keanekaragaman tersebut disatukan dengan slogan: "Bhinneka Tunggal Ika", walaupun berbeda-beda tetap satu juga" sebagai kekuatan yang tumbuh, hidup, mengakar dari kehidupan masyarakat Indonesia.

Di Provinsi Aceh, keberagaman masyarakat juga wujud dalam berbagai kehidupan bermasayarakat, salah satunya adalah adanya masyarakat hukum adat laot yang tunduk pada Panglima Laot. Masyarakat hukum adat laot merupakan masyarakat nelayan yang tunduk pada entitas tersendiri, dan telah ada sebelum terbentuknya Negara Kesatuan Republik Indonesia.

Saat ini, dari 23 Kota/kota di Provinsi Aceh, masyarakat hukum adat laot mendiami 18 Kota/kota yang terbagi dalam 176 wilayah lhok. Secara turun temurun masyarakat hukum adat laot mengelola wilayah kelola adat lebih kurang sejauh 4 mil dari garis pantai ke arah laut, dan 1 leun pukat atau dari pecah ombak sampai dengan anaman tahunan tak dapat tumbuh lagi ke arah darat (+-100 meter). Namun, dibeberapa wilayah lhok, luas wilayah kelola tersebut berbeda-beda. 
Model Penentuan Batas Wilayah Kelola Masyarakat Adat Laot; Studi Kasus Wilayah Lhok Kuala Cangkoi, Ulee Lhe Teuku Muttaqin Mansur, M. Adli, Sulaiman.

Dalam kontek kearifan lokal, wilayah kelola adat memiliki seperangkat aturan mengenai penggunaan alat tangkap, waktu, dan proses penangkapan. M. Adli Abdullah , dkk, mengatakan, konsep wilayah kelola adat laut menititik beratkan pada konsep ketersediaan dan keberlanjutan. Dalam rangka itu, menurut Sulaiman, dkk, dalam pengelolaan kawasan pesisir dan pulau-pulau kecil, bahwa masyarakat hukum adat laot mempunyai hak, antara lain: (a) akses terhadap bagian perairan pesisir yang sudah diberi izin; (b) mengusulkan wilayah penangkapan ikan secara tradisional; (c) mengusulkan wilayah masyarakat hukum adat (MHA); dan (d) melalukan kegiatan pengelolaan sumber daya pesisir berdasarkan hukum adat yang berlaku dan tidak bertentangan dengan undang-undang.

Dengan demikian, kearifan lokal merupakan anugerah yang tidak ternilai menjadi budaya yang hidup dalam masyarakat, berpangkal pada sistem nilai, dan religi yang dianut dalam komunitasnya. Dalam konteks ini, kearifan lokal adat laut dapat menjadi benteng strategis dalam rangka membangun dan meningkatkan ketahanan pangan masyarakat hukom adat laot (pesisir) dari ancaman perusak sumber daya perikanan dan pesisir.

\section{HASIL PENELITIAN DAN PEMBAHASAN}

\section{Mekanisme Penentuan WK-MHAL}

Penentuan WK-MHAL Lhok Kuala Cangkoi dilakukan melalui proses musyawarah (pertemuan) formal dan tidak formal dengan pemangku kepentingan WK-MHAL, masyarakat nelayan setempat, dan pemangku kepentingan perbatasan yang difasilitasi oleh Pengabdi dari Fakultas Hukum Universitas Syiah Kuala. Sebelum musyawarah inti yang membahas penentuan wilayah dilaksanakan, pihak pengabdi mengawali dengan kegiatan observasi dan menjalin komunikasi informal dengan Panglima Laot Lhok Kuala Cangkoi serta meminta mitra Jaringan Kuala memfasilitasi pertemuan dengan para stakeholder. Berikut dipaparkan gambar tahapan mekanisme penentuan WK-MHAL Lhok Kuala Cangkoi:

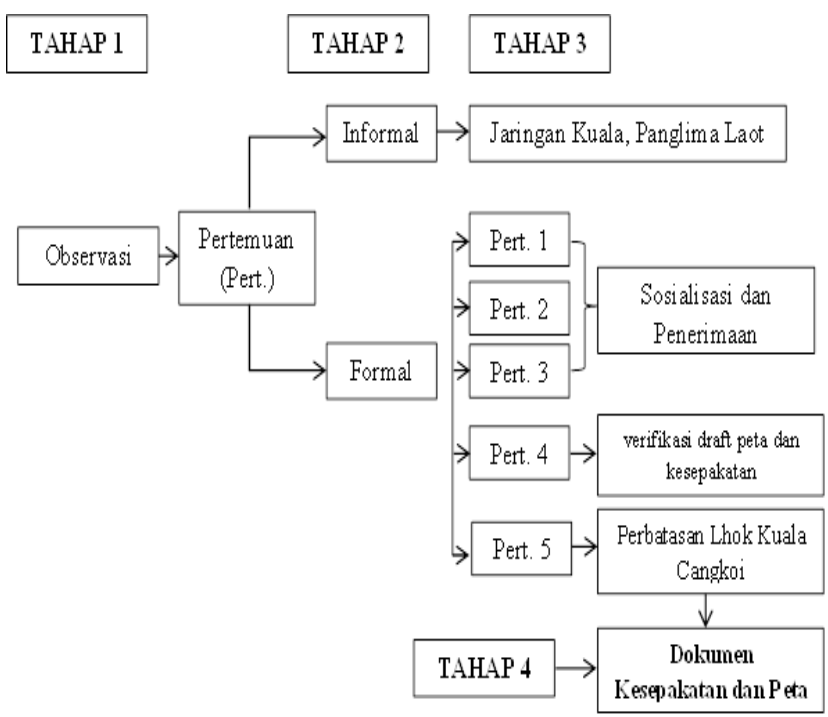

Gambar 1, Tahapan Penentuan WK-MHAL Lhok Kuala Cangkoi

Pada saat observasi dan komunikasi informal, Panglima Laot Lhok dan Panglima Laot Kota mendukung penuh penentuan WKMHAL. Namun, perlu segera disosialisasikan dalam pertemuan lebih formal kepada pihak- 
Model Penentuan Batas Wilayah Kelola Masyarakat Adat Laot; Studi Kasus Wilayah Lhok Kuala Cangkoi, Ulee Lhe

Teuku Muttaqin Mansur, M. Adli, Sulaiman.

pihak lain, dalam hal ini kepada Imeum Mukim dalam wilayah lhok, keuchik, dan nelayan. Tujuan pertemuan awal tersebut, untuk memberitahukan secara terbuka rencana kegiatan WK-HAL.

Menurut Sulaiman, ${ }^{2}$ setelah disampaikan maksud dan tujuan penentuan WK-MHAL Lhok Kuala Cangkoi, terdapat dinamika penting yang kemudian menjadi kesepakatan. Ada anggapan dari masyarakat bahwa kegiatan yang akan dilaksanakan adalah semacam proyek (pembangunan fisik). Oleh karena itu, sosialisasi dilakukan langsung ke wilayah Teupin-Teupin dalam wilayah Lhok oleh pengabdi.

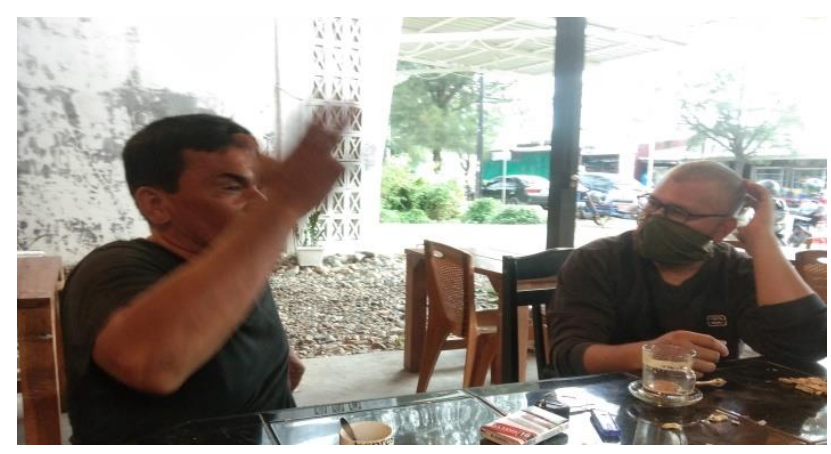

Gambarn 2, Tim pengabdi sedang melakukan interview dengan nelayan tentang batas wilayah kelola dan kesepakatan hokum adat laot bersama nelayan di Lhok Kuala Cangkoi.

Berdasarkan kesepakatan tersebut, selanjutnya dilakukan kembali sosialisasi sekaligus meminta masukan terkait dengan penentuan WK-MHAL dari sejumlah panglima teupin. Selain mendapatkan dukungan, tahap ini juga menerima masukan terkait dengan WKMHAL yang telah ada. Pada pertemuan di Teupin Teupin Cot Lambung, hadir juga

\footnotetext{
${ }^{2}$ Anggota Pengabdi, wawancara 29 Agustus 2019.
}

pembantu pengabdi pembuat peta WK-HAL. Keikutsertaan tim pembantu supaya langsung dapat menunjukkan wilayah dan batasan wilayah kelola kepada masyarakat dan stakeholder yang hadir.

Pada pertemuan selanjutnya, pengabdi sebagai fasilitator dibantu Jaringan Kuala menampilkan draft peta yang sudah dicetak di spanduk untuk dilihat bersama kembali. Pertemuan tersebut juga menghasilkan draft kesepakatan bersama tentang pengelolaan WKMHAL. Panglima Laot Lhok Lampuuk, menyepakati bahwa batasan WK-HAL berada di Ujong Raja sebagaimana peta yang dipaparkan. Namun, untuk Perwakilan Panglima Laot Kuala Cangkoi yang hadir masih mempermasalahkannya. Permasalahan tersebut akan didiskusikan kembali dengan nelayan dalam kawasan lhok tersebut. Atas dasar itu, pengabdi membuat peta WK-MHAL sesuai dengan kesepakatan tersebut. M. Adli ${ }^{3}$, anggota Pengabdi menjelaskan, draft peta dan kesepakatan sudah dihasilkan. Secara informal pun telah dikomunikasikan kembali kepada Panglima Laot Lhok dan Kota. Dalam waktu dekat ke depan akan dilakasankan peresmiannya. Waktu disesuaikan dengan ketersediaan waktu Walikota Banda Aceh sebagai pihak pemerintah yang akan menggunakan peta.

\footnotetext{
${ }^{3}$ Anggota Pengabdi, Wawancara, 29 Agustus 2019.
} 
Model Penentuan Batas Wilayah Kelola Masyarakat Adat Laot; Studi Kasus Wilayah Lhok Kuala Cangkoi, Ulee Lhe Teuku Muttaqin Mansur, M. Adli, Sulaiman.

\section{Kesepakatan WK-MHAL}

Sebagaimana diuraikan di atas, kesepakatan WK-MHAL yang telah disepakati berangkat dari kesadaran bersama bahwa sumber daya perikanan merupakan anugerah Allah swt yang jumlah terbatas, sehingga wajib dijaga, dipelihara, dan dikembangkan secara bersama-sama secara lestari dan berkelanjutan. Dengan memperhitungkan generasi mendatang, sumber daya perikanan dan ekosistem kelautan di wilayah Lhok Kuala Cangkoi Kota Banda Aceh telah menjadi sumber kehidupan warga yang harus diusahakan pemanfaatannya demi terwujudnya kemakmuran masyarakat. Salah satu cara menjaga sumber daya perikanan dan ekosistem kelautan adalah melalui pelaksanaan hukom adat laot dan pengaturan wilayah kelola hukom adat laot secara bijaksana.

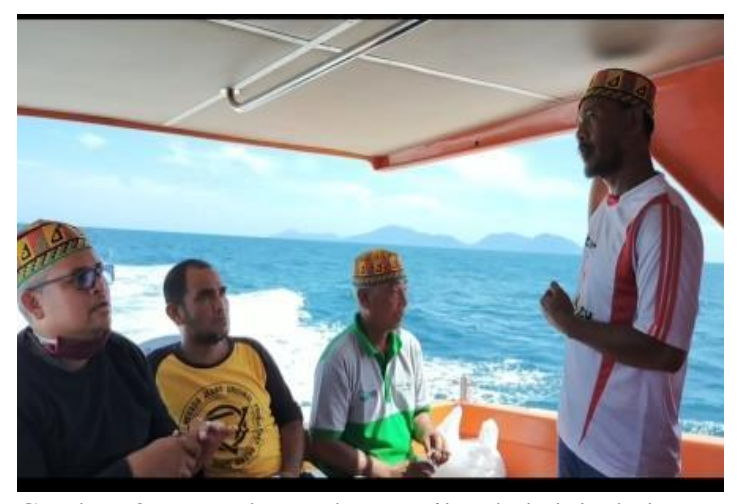

Gambar 3, Pengukuran batas wilayah kelola hokum adat laot bersama Panglima Laot Lhok Kuala Cangkoi.

Hukom adat laot diberlakukan oleh masyarakat nelayan untuk menjaga ketertiban dalam penangkapan ikan, melindungi wilayah tangkapan nelayan tradisional, dan menjaga kelestarian serta keberlanjutan sumber daya perikanan. Masyarakat juga sepakat bahwa,
WK-MHAL sebagai wilayah adat yang selama ini dimanfaatkan oleh masyarakat Hukom adat laot (nelayan tradisional) dari garis pantai sampai batas tertentu ke arah laut dan kearah darat dari pecah ombak sampai dengan tanaman tahunan tidak tumbuh.

Selanjutnya, pemanfaatan wilayah hukom adat laot Lhok Kuala Cangkoi dilaksanakan berdasarkan tata cara yang telah diatur dalam ketentuan hukom adat laot. Setiap orang tidak boleh memanfaatkan sumber daya perikanan dan ekosistem kelautan dalam wilayah kelola hukom adat laot lhok Kuala Cangkoi dengan cara-cara yang merusak lingkungan. Setiap orang yang melanggar akan dikenai sanksi berdasarkan ketentuan hukom adat laot.

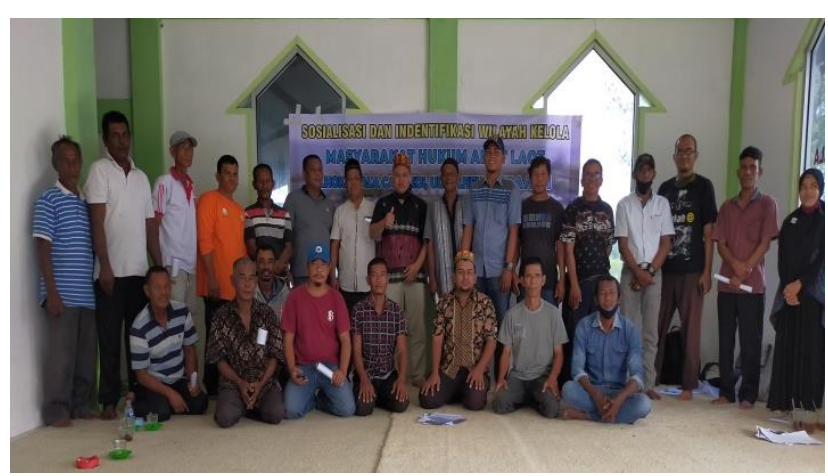

Gambar 4, Sosialisasi batas wilayah kelola dan kesepakatan hokum adat laot dan bersama Panglima Laot, nelayan dan pemangku kepentingan di Lhok Kuala Cangkoi.

Untuk mendukung tetap tegaknya hukom adat laot, diperlukan keikutsertaan pemerintah dan aparat keamanan negara untuk melindungi Panglima Laot saat menetapkan sanksi-sanksi adat. Secara umum terdapat delapan kesepakatan yang telah dihasilkan 
Model Penentuan Batas Wilayah Kelola Masyarakat Adat Laot; Studi Kasus Wilayah Lhok Kuala Cangkoi, Ulee Lhe

Teuku Muttaqin Mansur, M. Adli, Sulaiman.

dalam pertemuan dengan panglima laot, pemangku kepentingan dan stake holder lainnya. Kedelapa peraturan itu meliputi beberapa bagian yaitu tentang batas wilayah kelola dan tujuan, kewenangan panglima laot lhok dan panglima teupin, dan tata cara meupayang / penangkapan ikan. Untuk tata cara meupanyang maka dikelompokkan dalam dua bagian yaitu tentang tata cara meupayang (penangkapan ikan) dengan boat labi-labi/pukat laut, tata cara meupayang (penangkapan ikan) dengan menggunakan pukat darat, dan tata cara meupayang (penangkapan ikan) dengan menggunakan alat tangkap jarring. Selanjutnya peraturan yang dihasilkan adalah berkaitan hari pantangan melaut, larangan khusus menggunakan bom, pembiusan dan kompresor, dan sanksi para pelanggar.

\section{SIMPULAN}

WK-MHAL disepakati setelah dilakukan sejumlah pertemuan dengan stakeholder dan masyarakat nelayan. Peta WK-MHAL Lhok Lamteungoh sangat penting untuk menjelaskan secara tertulis kepada pihak-pihak yang berkepentingan. Peta ini juga dapat dijadikan rujukan dalam penetapan zonasi dalam rencana Qanun Aceh tentang RZWP3K. 


\section{DAFTAR PUSTAKA}

A. Sonny Keraf, Etika Lingkungan, (Jakarta: Penerbit Kompas, 2005).

Dominikus Rato, Hukum dalam Perspektif Konstruksi Sosial, (Jember: Fakultas Hukum Universitas Jember, 2009).

I. Nyoman Nurjaya, Pengelolaan Sumber Daya Alam, Perspektif Antropologi Hukum (Jakarta: Pustaka Publisher, 2008).

M. Adli Abdullah, Sulaiman, dan Teuku Muttaqin Mansur, 2006. Selama Kearifan adalah Kekayaan, Eksistensi Panglima Laot dan Hukom Adat Laot di Aceh, Jakarta: Yayasan Kehati.

Sulaiman, Syamsul Bahri, dan M. Adli Abdullah, 2016. Sisi Lain Ulayat Laut, Perspektif Hukum Pengelolaan Pesisir Berbasis Hukum Adat Laut, Banda Aceh, Bandar Publishing.

Teuku Muttaqin Mansur dan Marzuki,’Pengelolaan Kawasan Konservasi Perairan Daerah Di Provinsi Aceh Berbasis Kearifan Lokal (Hukum Adat Laot)", Jurnal Geuthèë: Penelitian Multidisplin, Vol 1 No 1, (Maret 2018), (65-74).

Teuku Muttaqin Mansur, 2018, Hukum Adat Perkembangan dan Pembaharuannya di Indonesia, Banda Aceh, Syiah Kuala University Press.

Teuku Muttaqin Mansur, Yunita, et.all., 2020, The Effectiveness of the Implementation of Customary Fines in settlement of Seclusion Cases in Banda Aceh, Sriwijaya Law Review, DOI: $10.28946 /$ slrev.vol4.Iss 2.404.pp52-61.

Teuku Muttaqin Mansur, Sulaiman, et.all. Adat Court in Aceh, Indonesia: A Review of Law, Jurnal Ilmiah Peuradeun Vol 8, No 2, Page: 423-442.

\section{Undang-Undang}

Undang-undang Dasar 1945.

Undang-Undang Nomor 45 Tahun 2009 tentang Perubahan UU Nomor 31 Tahun 2004 tentang Perikanan.

Undang-Undang Nomor 1 tahun 2014 tentang Pengelolaan Wilayah Pesisir dan Pulau-pulau Kecil.

Permen KP Nomor 8 tahun 2008 tentang Tata Cara Penetapan Wilayah Kelola Masyarakat Hukum Adat Dalam Pemanfaatan Ruang di Wilayah Pesisir dan Pulau-Pulau Kecil.

Qanun Aceh Nomor 7 Tahun 2010 tentang Perikanan

Qanun Aceh Nomor 1 Tahun 2020 tentang Rencana Zonasi Wilayah Pesisir dan Pulau-pulau Kecil. 